\title{
ANALISIS KETERBACAAN BUKU AJAR BAHASA JAWA \\ KELAS IV SEKOLAH DASAR SE-KARESIDENAN MADIUN
}

\author{
Endang Sri Maruti, Rissa Prima Kurniawati \\ Universitas PGRI Madiun, endangmaruty@yahoo.co.id \\ Universitas PGRI Madiun, rissaprimakurniawati14@gmail.com
}

\begin{abstract}
One of the problems that arise in learning the Java language is when a student must be able to understand the textbook content used by teachers in the classroom. Many words or sentences in the Java language textbook that is difficult for students to understand because it feels foreign so that students do not understand what the meaning of the word or sentence. Based on the results of preliminary observations, students of the sixth grade of elementary school are not able to master the content of the material in textbooks that should be used for fourth grade students of elementary school. Therefore, this study aims to find out how much textbooks and textbooks that have been used in SD in Madiun Residency with each class level. Data analysis method used is with Fry Graph and Klos technique. The result of the research shows that the area that has been using textbook that is in accordance with the level of legibility is the area of Madiun, Magetan and Ngawi, while the other three regions of Pacitan, Ponorogo, and Madiun Kota are not suitable because they are too high, And 8, that means the textbook is appropriate for the junior level.
\end{abstract}

Key words: Analysis of textbooks legibility, Javanese language

\section{PENDAHULUAN}

Keberhasilan peserta didik dalam menyelesaikan program kajian yang telah ditetapkan banyak ditentukan oleh kemampuan peseta didik itu untuk menyerap materi yang telah ditetapkan oleh para pengajar. Salah satu yang akan menentukan kadar penyerapan materi tersebut adalah terbaca tidaknya buku yang ditetapkan sebagai buku pegangan. Artinya apakah tingkat kesulitan bahasa yang digunakan dalam buku itu sesuai dengan tingkat kemampuan berbahasa peserta didik. Hal di atas akan menjadi masalah untuk buku-buku terutama yang tertulis dalam bahasa Jawa, yang dianggap bahasa asing pada masa sekarang ini. 
Sebagai sarana dalam upaya mencerdaskan bangsa, buku memegang peranan yang sangat penting. Permasalahannya adalah buku teks yang dipersiapkan dengan matang seringkali menyulitkan siswa untuk memahaminya. Hal itu dibuktikan dari data hasil nilai siswa yang mengerjakan contoh soal dari buku ajar Bahasa Jawa diperoleh tidak memenuhi KKM. Karena itu, yang perlu diperhatikan dalam penyusunan bahan ajar adalah kalimat karena kalimat-kalimat merupakan satu-satuan kebahasaan yang sangat penting. Pemilihan kalimat tepat dengan diksi yang sesuai dengan tingkatannya menjadi penentu keterbacaan buku tersebut.

Agar buku ajar memenuhi syarat dan tujuan yang diharapkan, tingkat keterbacaannya harus sesuai dengan tingkat kemampuan dan penalaran siswa. Kesesuaian tingkat keterbacaan suatu buku sangat penting karena hal itu akan sangat berpengaruh terhadap motivasi dan minat siswa untuk membaca. Untuk menghindari permasalahan seperti itu, diperlukan suatu penelitian tentang keterbacaan buku ajar, khususnya buku ajar tematik tingkat sekolah dasar. Keterbacaan diperlukan untuk mengetahui tingkat kesulitan atau kemudahan suatu teks dipahami oleh siswa. Penelitian ini akan dibatasi pada keterbacaan buku ajar bahasa Jawa kelas 4 yang digunakan oleh SD se-Karesidenan Madiun mengingat karesidenan ini memiliki kesamaan buku yang digunakan.

\footnotetext{
Indikator keterbacaan suatu teks bukan dialog adalah keterbacaan masing-masing paragrafnya. Untuk dapat memahami suatu teks perlu pemahaman yang utuh terhadap masing-masing paragraf pembentuk teks. Cacah kalimat dalam suatu paragraf dapat dijadikan indikator sederhana-tidaknya atau kompleks-tidaknya pokok pikiran yang dikembangkan dalam sebuah paragrap (Pranowo, 2000:8). Ini berarti bahwa cacah kalimat berpengaruh terhadap tingkat keterbacaan paragraf. Semakin berkurangnya cacah kalimat dari batas tertentu dalam suatu paragraf dapat dijadikan indokator bahwa paragraf yang
} 
bersangkutan semakin padat dan informasi yang disampaikan secara eksplisit semakin sedikit. Sebaliknya, bila cacah kalimatnya lebih banyak dari yang dibutuhkan, di dalam paragraf itu akan terjadi keterulangan (redundansi) kalimat yang akhirnya akan mempengaruhi proses pemahaman pembaca terhadap paragraf tersebut.

Formula keterbacaan saat ini kebanyakan menggunakan dua tolok ukur, yakni (a) panjang-pendeknya kalimat, dan (b) tingkat kesulitan kata (Laksono, 2007:4.5). Semakin panjang kalimat dan semakin panjang kata-kata maka bahan bacaan yang dimaksud semakin sukar. Begitu pula sebaliknya, apabila kalimat dan katanya pendek-pendek maka wacana yang dimaksud tergolong wacana yang mudah.

Dalam menentukan keterbacaan suatu teks pelajaran dilakukan kajian pada tiga hal, yaitu keterbacaan teks, latar belakang pembaca, dan interaksi antara teks dengan pembaca. Hal ini sesuai dengan konsep dasar yang diungkapkan Rusyana (1984:213) bahwa keterbacaan berhubungan dengan peristiwa membaca yang dilakukan seseorang, sehingga akan bertemali dengan aspek (1) pembaca; (2) bacaan; dan (3) latar. Ketiga komponen tersebut akan dapat menerangkan keterbacaan buku teks pelajaran.

Tulisan ini lebih dominan mengungkap tentang hasil kajian keterbacaan buku teks pelajaran, khususnya pelajaran bahasa daerah (Jawa) di tingkat Sekolah Dasar (SD). Keterbacaan yang dimaksud adalah kemampuan berinteraksi penggunaan Bahasa Jawa dalam buku teks dengan peserta didik sebagai pembaca.

\section{METODE PENELITIAN}

Penelitian ini bertujuan untuk mengetahui tingkat keterbacaan buku ajar Bahasa Jawa kelas 4 untuk siswa sekolah dasar se karesidenan Madiun. 
Berdasarkan tujuan tersebut, maka penelitian ini termasuk pada jenis penelitian kuantitatif dengan penghitungan-penghitungan menurut rumus yang sudah ditentukan. Objek penelitian ini adalah keterbacaan buku teks mata pelajaran bahasa Jawa kelas 4 tingkat Sekolah Dasar se-karesidenan Madiun sedangkan subjek penelitiannya adalah buku ajar bahasa Jawa kelas 4 tingkat Sekolah Dasar se-karesidenan Madiun. Sesuai dengan asumsi dasar dan data awal maka penelitian ini mengambil sampel masing-masing dua sekolah pada tiap kabupaten di karesidenan Madiun.

Sesuai dengan data dan sumber data di lapangan maka teknik pengambilan data yang akan digunakan dalam penelitian ini adalah sebagai berikut.

1. Data buku teks pembelajaran bahasa daerah (Jawa) diambil dengan teknik pustaka.

2. Data evaluasi diambil dengan teknik dokumentasi

Teknik analisis data yang digunakan dalam penelitian ini adalah dengan menggunakan formula keterbacaan Fry dan dengan prosedur klose.

\section{HASIL PENELITIAN DAN PEMBAHASAN}

Pada bagian ini dipaparkan hasil analisis keterbacaan buku teks yang berupa buku paket dan LKS yang digunakan siswa SD Kelas IV se-karesidenan Madiun yang terdiri atas Kabupaten Pacitan, Ponorogo, Madiun, Ngawi, Magetan, dan Kota Madiun. Masing-masing wilayah diambil 2 sampel buku teks. Berikut ini hasil analisis keterbacaan secara lebih lengkap.

\section{Hasil Analisis Data Kabupaten Pacitan}

Perhitungan total tingkat keterbacaan dari teks awal sampai akhir pada buku paket adalah sebagai berikut. 
Endang Sri Maruti, Analisis Keterbacaan Buku... (hlm. 21-40)

\begin{tabular}{lcc}
\hline $\begin{array}{c}\text { Wacana sampel (100 } \\
\text { kata) }\end{array}$ & Jumlah Suku Kata & Jumlah Kalimat \\
\hline Bagian awal & 140 & 8 \\
Bagian tengah & 149 & 8,3 \\
Bagian akhir & 142 & 6,7 \\
\hline \multicolumn{1}{c}{ Jumlah } & 431 & 23 \\
\hline \multicolumn{1}{c}{ Rata-rata } & 144 & 7,7 \\
\hline
\end{tabular}

Rata-rata jumah kalimat $=8+8,3+6,7=23 / 3=7,7$ kalimat

Jumlah suku kata $=140+149+142=431 / 3=144$ suku kata

Setelah dilihat pada grafik Fry, maka titik temunya ada di wilayah 7.

Perkiraan tingkat keterbacaan $=(7-1), 7,(7+1)$

Dengan demikian, buku ajar tersebut cocok untuk siswa kelas 6 (SD), dan 7 dan 8 (SMP). Selain dianalisis berdasarkan grafik fry, buku teks di atas juga dianalisis berdasarkan teknik klos. Adapun metode analisis pada teknik ini adalah dengan cara menghilangkan kata kelima dari setiap kalimat dimulai pada kalimat kedua, kemudian teks yang rumpang ini diisi oleh beberapa siswa sampel kelas IV SD di SD sampel di Kabupaten Pacitan. Adapun hasil yang diperoleh sebagai berikut.

\begin{tabular}{llcl}
\hline NO. & NAMA & JUMLAH & KATEGORI \\
\hline 1. & Ridchi A.L & $(5: 20) \times 100 \%=25 \%$ & Frustasi
\end{tabular}


2. Silfi Eriani

$(8: 20) \times 100 \%=40 \% \quad$ Frustasi

3. Rendy Eko Y.

$(10: 20) \times 100 \%=50 \%$

Frustasi

$\begin{array}{lll}\text { Rata-rata } & 38 \% & \text { Frustasi }\end{array}$

Berdasarkan tabel di atas, subjek kelas IV SD memiliki tingkat keterbacaan yang frustasi. Itu artinya buku teks ini belum tepat sasaran atau belum sesuai dengan kelasnya.

Berdasarkan hasil kedua teknik analisis keterbacaan yang telah dilakukan, dapat disimpulkan bahwa buku ajar yang dikembangkan dan digunakan di Kabupaten Pacitan belum tepat sasaran karena belum sesuai dengan tingkat pembacanya, sehingga peserta didik selaku pembaca belum paham dengan isi buku tersebut. Adapun gambarannya nampak pada diagram di bawah ini.

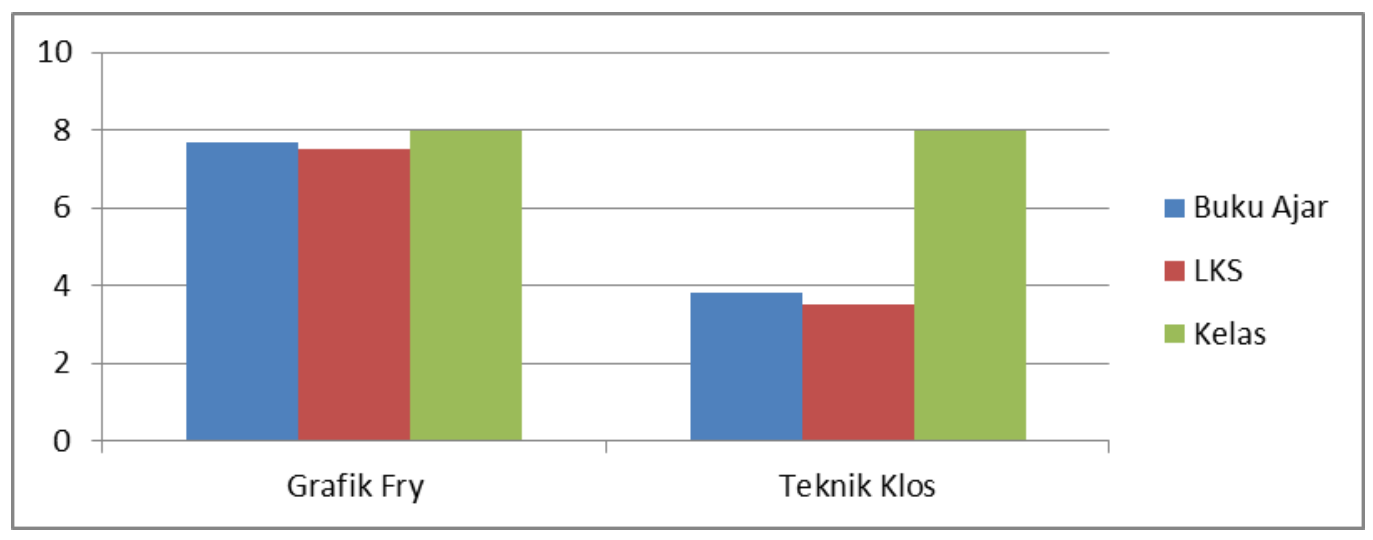

Diagram 1. Hasil Keterbacaan Buku Ajar di Kabupaten Pacitan

Berdasarkan diagram di atas, dapat disimpulkan bahwa buku ajar yang digunakan di Kabupaten Pacitan belum tepat sasaran, karena berdasarkan penghitungan buku ajar tersebut cocok untuk siswa kelas 6 (SD), 7, dan 8 (SMP).

26 | http://journal.unesa.ac.id/index.php/paramasastra 
Endang Sri Maruti, Analisis Keterbacaan Buku... (hlm. 21-40)

\section{Hasil Analisis Data Kabupaten Ponorogo}

Perhitungan total tingkat keterbacaan dari teks awal sampai akhir buku ajar adalah sebagai berikut.

\begin{tabular}{|c|c|c|}
\hline $\begin{array}{c}\text { Wacana sampel (100 } \\
\text { kata) }\end{array}$ & Jumlah Suku Kata & Jumlah Kalimat \\
\hline Bagian awal & 145 & 5,8 \\
\hline Bagian tengah & 155 & 7,4 \\
\hline Bagian akhir & 156 & 9,5 \\
\hline Jumlah & 456 & 22,7 \\
\hline Rata-rata & 152 & 7,6 \\
\hline
\end{tabular}

Rata-rata jumah kalimat $=5,8+7,4+9,5=22,7 / 3=7,6$ kalimat

Jumlah suku kata $=145+155+156=456 / 3=152$ suku kata

Setelah dilihat pada grafik Fry, maka titik temunya ada di wilayah 8 .

Perkiraan tingkat keterbacaan $=(8-1), 8,(8+1)$

Dengan demikian, buku ajar tersebut cocok untuk siswa kelas 7, 8, dan 9 (SMP).

Selain dianalisis berdasarkan grafik fry, buku teks di atas juga dianalisis berdasarkan teknik klos. Adapun hasil yang diperoleh sebagai berikut. 


\begin{tabular}{llll}
\hline NO. & NAMA & \multicolumn{1}{c}{ JUMLAH } & KATEGORI \\
\hline 1. & Nindya Gadis & $(7: 15) \times 100 \%=47 \%$ & Frustasi \\
2. & Prasetyo & $(4: 15) \times 100 \%=27 \%$ & Frustasi \\
3. & Zaky Gunawan & $(6: 15) \times 100 \%=40 \%$ & Frustasi \\
\hline & Rata-rata & $45 \%$ & Frustasi \\
\hline
\end{tabular}

Berdasarkan tabel di atas, subjek kelas IV SD memiliki tingkat keterbacaan yang frustasi. Itu artinya buku LKS ini belum tepat sasaran atau belum sesuai dengan kelasnya.

Berdasarkan hasil kedua teknik analisis keterbacaan di atas, dapat disimpulkan bahwa buku ajar yang dikembangkan dan digunakan di Kabupaten Ponorogo belum tepat sasaran karena belum sesuai dengan tingkat pembacanya, sehingga peserta didik selaku pembaca belum paham dengan isi buku tersebut. Adapun gambarannya nampak pada diagram di bawah ini.

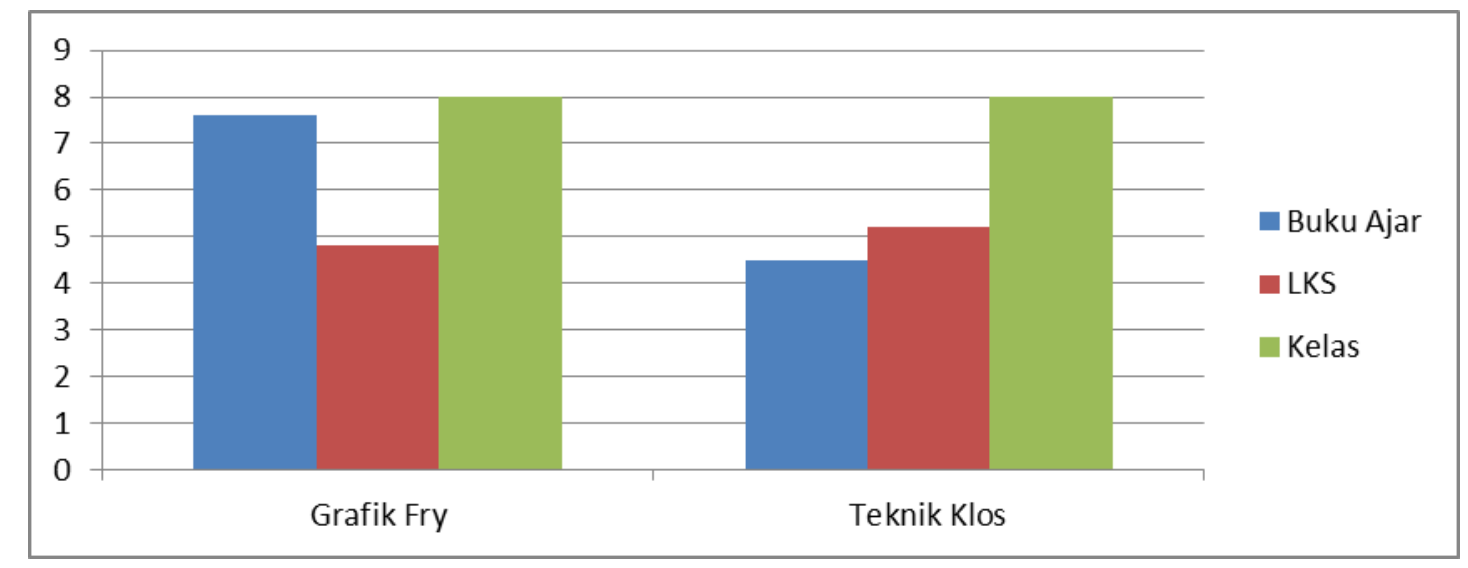

Diagram 2. Hasil Keterbacaan Buku Ajar di Kabupaten Ponorogo

28 | http://journal.unesa.ac.id/index.php/paramasastra 
Endang Sri Maruti, Analisis Keterbacaan Buku... (hlm. 21-40)

Berdasarkan diagram di atas, dapat disimpulkan bahwa buku ajar yang digunakan di Kabupaten Ponorogo belum tepat sasaran, karena berdasarkan penghitungan buku ajar tersebut cocok untuk siswa kelas 7, 8, dan 9 (SMP).

\section{Hasil Analisis Data Kabupaten Madiun}

Perhitungan total tingkat keterbacaan dari teks awal sampai akhir adalah sebagai berikut.

\begin{tabular}{|c|c|c|}
\hline $\begin{array}{c}\text { Wacana sampel (100 } \\
\text { kata) }\end{array}$ & Jumlah Suku Kata & Jumlah Kalimat \\
\hline Bagian awal & 146 & 11,8 \\
\hline Bagian tengah & 128 & 10,6 \\
\hline Bagian akhir & 139 & 12,2 \\
\hline Jumlah & 413 & 34,6 \\
\hline Rata-rata & 138 & 11,5 \\
\hline
\end{tabular}

Rata-rata jumlah kalimat $=11,8+10,6+12,2=34,6 / 3=11,5$ kalimat

Jumlah suku kata $=146+128+139=423 / 3=138$ suku kata

Setelah dilihat pada grafik Fry, maka titik temunya ada di wilayah 4.

Perkiraan tingkat keterbacaan $=(4-1), 4,(4+1)$

Dengan demikian, buku ajar tersebut cocok untuk siswa kelas 3, 4, dan 5 SD. 
Selain dianalisis berdasarkan grafik fry, buku teks di atas juga dianalisis berdasarkan teknik klos. Adapun hasil yang diperoleh sebagai berikut.

\begin{tabular}{llll}
\hline NO. & NAMA & \multicolumn{1}{c}{ JUMLAH } & KATEGORI \\
\hline 1. & Azkiya M. & $(12: 15) \times 100 \%=80 \%$ & Independen \\
2. & Bagas Biyantoro & $(10: 15) \times 100 \%=60 \%$ & Independen \\
3. & Chika Nastasya & $(10: 15) \times 100 \%=60 \%$ & Independen \\
\hline & Rata-rata & $70 \%$ & Independen \\
\hline
\end{tabular}

Berdasarkan tabel di atas, subjek kelas IV SD memiliki tingkat keterbacaan yang independen. Itu artinya buku LKS ini sudah tepat sasaran atau sudah sesuai dengan kelasnya.

Berdasarkan hasil kedua teknik analisis keterbacaan di atas, dapat disimpulkan bahwa buku ajar yang dikembangakn dan digunakan di Kabupaten Madiun sudah tepat sasaran karena sudah sesuai dengan tingkat pembacanya, sehingga peserta didik selaku pembaca sudah paham dengan isi buku ajar tersebut. Adapun gambarannya nampak pada diagram di bawah ini. 


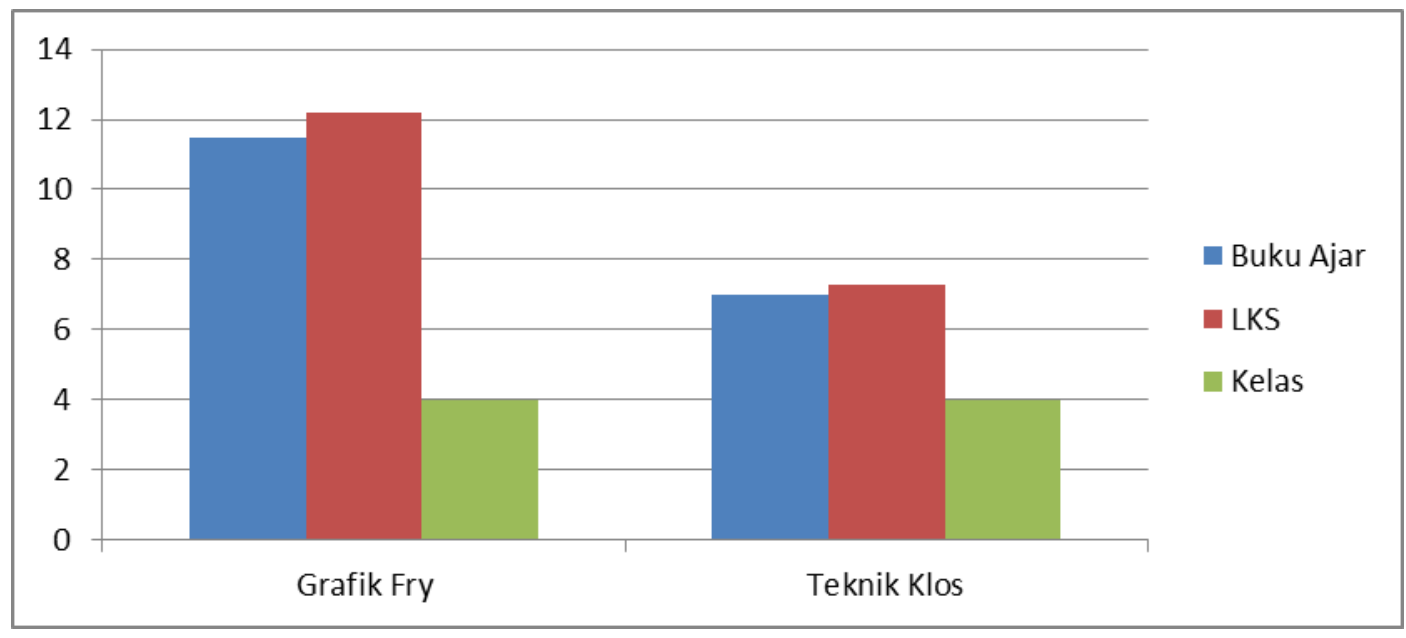

Diagram 3. Hasil Keterbacaan Buku Ajar di Kabupaten Madiun

Berdasarkan diagram di atas, dapat disimpulkan bahwa buku ajar yang digunakan di Kabupaten Madiun sudah tepat sasaran, karena berdasarkan penghitungan buku ajar tersebut cocok untuk siswa kelas 3, 4, dan 5 (SD).

\section{Hasil Analisis Data Kabupaten Magetan}

Perhitungan total tingkat keterbacaan dari teks awal sampai akhir adalah sebagai berikut.

\begin{tabular}{lcc}
\hline Wacana sampel (100 kata) & Jumlah Suku kata & Jumlah Kalimat \\
\hline Bagian awal & 158 & 12,8 \\
Bagian tengah & 128 & 10,8 \\
Bagian akhir & 137 & 6,04 \\
\hline
\end{tabular}




$\begin{array}{lll}\text { Jumlah } & 423 & 29,64\end{array}$

$\begin{array}{lll}\text { Rata-rata } & 141 & 9,88\end{array}$

Rata-rata jumah kalimat $=(12,8+10,8+6,04) / 3=29,64 / 3=9,88$ kalimat Jumlah suku kata $(158+128+137) / 3=423 / 3=141$ suku kata

Setelah dilihat pada grafik Fry, maka titik temunya ada di wilayah 6.

Perkiraan tingkat keterbacaan $=(6-1), 6,(6+1)$

Dengan demikian, buku ajar tersebut cocok untuk siswa kelas 5, 6, dan 7 (SMP).

Selain dianalisis berdasarkan grafik fry, buku teks di atas juga dianalisis berdasarkan teknik klos. Adapun hasil yang diperoleh sebagai berikut.

\begin{tabular}{llcl}
\hline NO & \multicolumn{1}{c}{ NAMA } & JUMLAH & KATEGORI \\
\hline 1 & Fitriana Yosa Dewi O & $(11: 15) \times 100 \%=73,3 \%$ & Independen/bebas \\
2 & Cahyo Tri A. & $(12: 15) \times 100 \%=80 \%$ & Independen/bebas \\
3 & Hanafi Maulana A. & $(12: 15) \times 100 \%=80 \%$ & Independen/bebas \\
\hline & Rata-rata & $78 \%$ & Independen/bebas \\
\hline & Berdasarkan tabel di atas, subjek kelas IV & SD memiliki tingkat
\end{tabular}
keterbacaan yang independen/bebas. Itu artinya buku teks ini sudah tepat sasaran atau sudah sesuai dengan kelasnya.

Berdasarkan hasil kedua teknik analisis keterbacaan di atas, dapat disimpulkan bahwa buku teks yang dikembangkan dan digunakan di Kabupaten 32 | http://journal.unesa.ac.id/index.php/paramasastra 
Endang Sri Maruti, Analisis Keterbacaan Buku... (hlm. 21-40)

Magetan sudah tepat sasaran karena sudah sesuai dengan tingkat pembacanya, sehingga peserta didik selaku pembaca belum paham dengan isi buku teks tersebut.

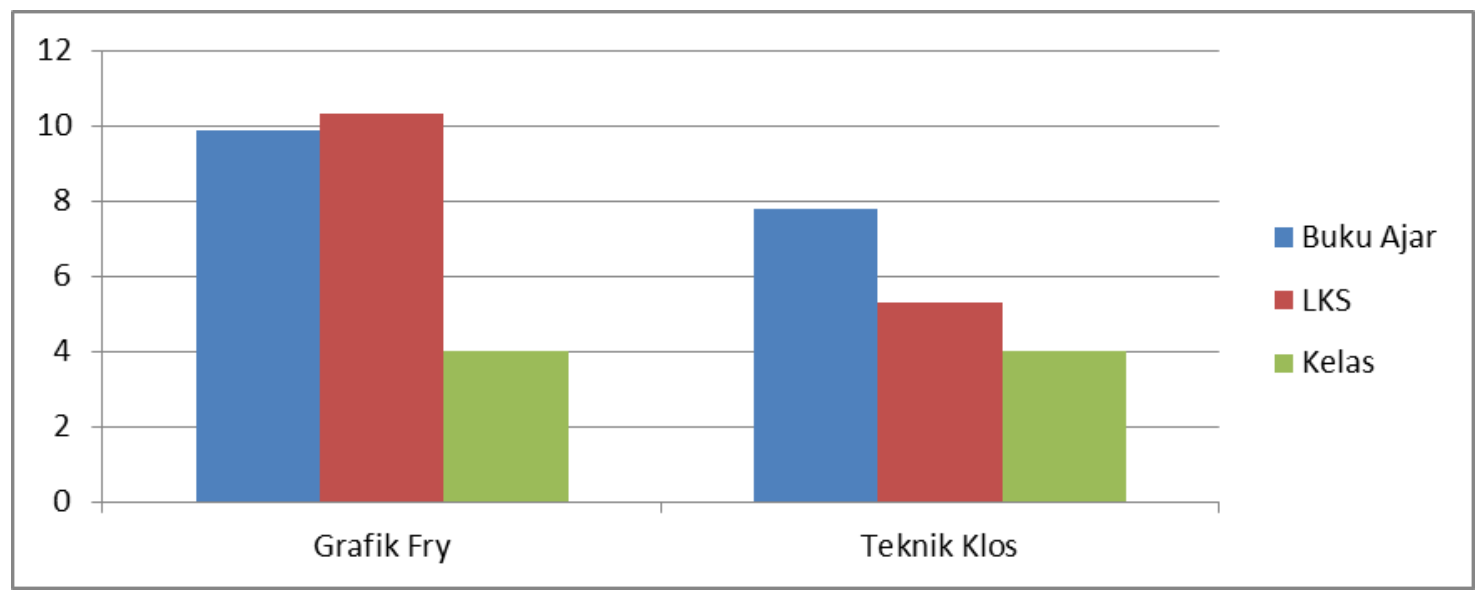

Berdasarkan diagram di atas, dapat disimpulkan bahwa buku ajar yang digunakan di Kabupaten Magetan sudah tepat sasaran, karena berdasarkan penghitungan buku ajar tersebut cocok untuk siswa kelas 3, 4, dan 5 (SD).

\section{Hasil Analisis Data Kabupaten Madiun}

Perhitungan total tingkat keterbacaan dari teks awal sampai akhir adalah sebagai berikut.

\begin{tabular}{lcc}
\hline Wacana sampel (100 kata) & Jumlah Suku kata & Jumlah Kalimat \\
\hline Bagian awal & 141 & 9,5 \\
Bagian tengah & 134 & 10,4 \\
Bagian akhir & 137 & 9,7 \\
\hline
\end{tabular}




Jumlah $\quad 412 \quad 29,6$

$\begin{array}{ll}\text { Rata-rata } \quad 137,3=137 & 9,87\end{array}$

Rata-rata jumah kalimat $=(9,5+10,4+9,7) / 3=29,6 / 3=9,87=9,9$ kalimat Jumlah suku kata $(141+134+137) / 3=412 / 3=137,3=137$ suku kata

Setelah dilihat pada grafik Fry, maka titik temunya ada di wilayah 5

Perkiraan tingkat keterbacaan $=(5-1), 5,(5+1)$

Dengan demikian, buku ajar tersebut cocok untuk siswa kelas 4, 5, dan 6.

Selain dianalisis berdasarkan grafik fry, buku teks di atas juga dianalisis berdasarkan teknik klos. Adapun metode analisis pada teknik ini adalah dengan cara menghilangkan kata kelima dari setiap kalimat dimulai pada kalimat kedua, kemudian teks yang rumpang ini diisi oleh beberapa siswa sampel kelas IV SD di SD sampel di Kabupaten Ngawi. Adapun hasil yang diperoleh sebagai berikut.

\begin{tabular}{llcl}
\hline NO & \multicolumn{1}{c}{ NAMA } & JUMLAH & KATEGORI \\
\hline 1 & Risky Wahyu I. C. & $(3: 15) \times 100 \%=20 \%$ & Frustasi \\
2 & Siti Fatimah & $(1: 15) \times 100 \%=6,7 \%$ & Frustasi \\
3 & Nofiana Fitri S. & $(9: 15) \times 100 \%=60 \%$ & Instruksional \\
\hline & Rata-rata & $29 \%$ & Frustasi \\
\hline
\end{tabular}


Endang Sri Maruti, Analisis Keterbacaan Buku... (hlm. 21-40)

Berdasarkan tabel di atas, subjek kelas IV SD memiliki tingkat keterbacaan yang frustasi. Itu artinya buku teks ini belum tepat sasaran atau belum sesuai dengan kelasnya.

Berdasarkan hasil kedua teknik analisis keterbacaan di atas, dapat disimpulkan bahwa buku teks yang dikembangkan dan digunakan di Kabupaten Ngawi belum tepat sasaran karena belum sesuai dengan tingkat pembacanya, sehingga peserta didik selaku pembaca belum paham dengan isi buku teks tersebut.

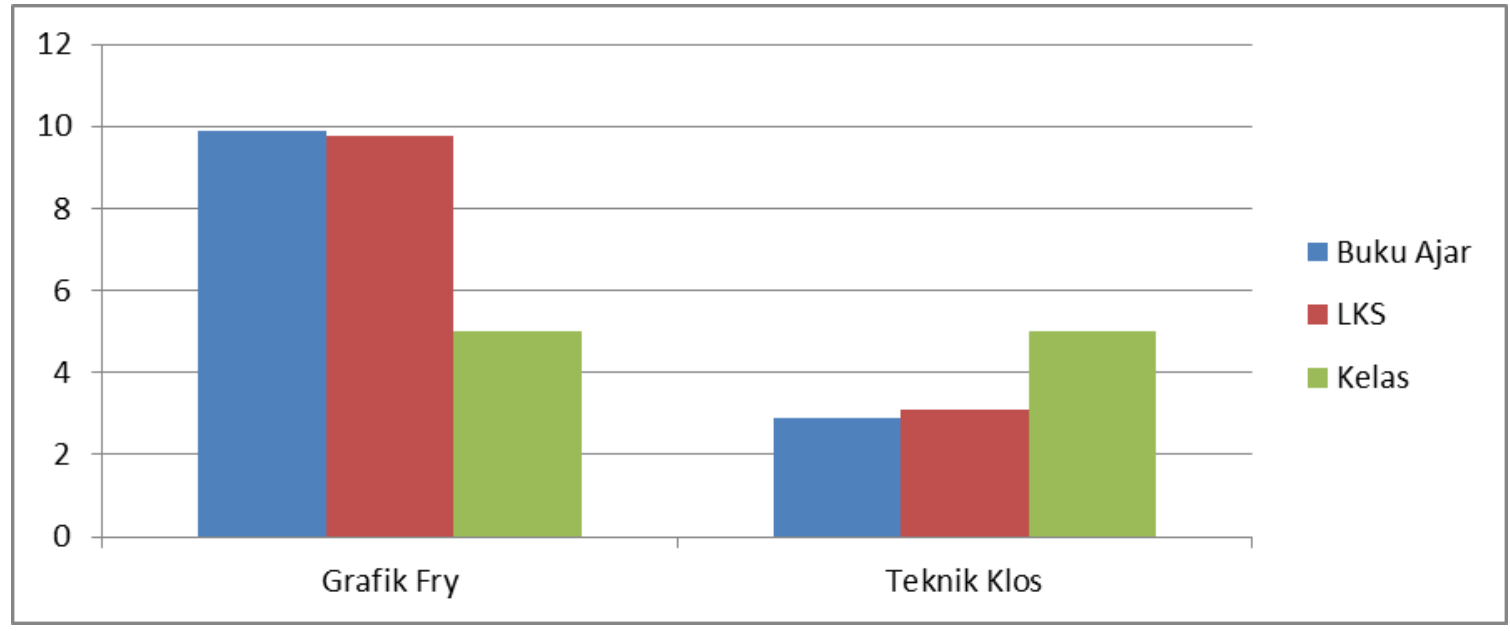

Berdasarkan diagram di atas, dapat disimpulkan bahwa buku ajar yang digunakan di Kabupaten Ngawi sudah tepat sasaran, karena berdasarkan penghitungan buku ajar tersebut cocok untuk siswa kelas 4, 5, dan 6 (SD). 


\section{Hasil Analisis Data Kota Madiun}

Perhitungan total tingkat keterbacaan dari teks awal sampai akhir adalah sebagai berikut.

\begin{tabular}{lcc}
\hline Wacana sampel (100 kata) & Jumlah Suku kata & Jumlah Kalimat \\
\hline Bagian awal & 142 & 9,4 \\
Bagian tengah & 154 & 7,7 \\
Bagian akhir & 142 & 6,6 \\
\hline \multicolumn{1}{c}{ Jumlah } & 438 & 23,7 \\
\hline \multicolumn{1}{c}{ Rata-rata } & 146 & 7,9 \\
\hline
\end{tabular}

Rata-rata jumah kalimat $=(9,4+7,7+6,6) / 3=23,7 / 3=7,9$ kalimat

Jumlah suku kata $(142+154+142) / 3=438 / 3=146$ suku kata

Setelah dilihat pada grafik Fry, maka titik temunya ada di wilayah 7

Perkiraan tingkat keterbacaan $=(7-1), 7,(7+1)$

Dengan demikian, buku ajar tersebut cocok untuk siswa kelas 6, 7, dan 8 (SMP).

Selain dianalisis berdasarkan grafik fry, buku teks di atas juga dianalisis berdasarkan teknik klos. Adapun metode analisis pada teknik ini adalah dengan cara menghilangkan kata kelima dari setiap kalimat dimulai pada kalimat kedua, kemudian teks yang rumpang ini diisi oleh beberapa siswa sampel kelas IV SD di SD sampel di Kota Madiun. Adapun hasil yang diperoleh sebagai berikut. 
Endang Sri Maruti, Analisis Keterbacaan Buku... (hlm. 21-40)

\begin{tabular}{lccl}
\hline NO & NAMA & JUMLAH & KATEGORI \\
\hline 1 & Nely Najwa A. & $(4: 15) \times 100 \%=26,7 \%$ & Frustasi \\
2 & Aulia Friska A. F. & $(4: 15) \times 100 \%=26,7 \%$ & Frustasi \\
3 & Febri Cantika K. & $(5: 15) \times 100 \%=33,3 \%$ & Frustasi \\
\hline & Rata-rata & $29 \%$ & Frustasi \\
\hline
\end{tabular}

Berdasarkan tabel di atas, subjek kelas IV SD memiliki tingkat keterbacaan yang frustasi. Itu artinya buku teks ini belum tepat sasaran atau belum sesuai dengan kelasnya.

Berdasarkan hasil kedua teknik analisis keterbacaan di atas, dapat disimpulkan bahwa buku teks yang dikembangkan dan digunakan di Kota Madiun belum tepat sasaran karena belum sesuai dengan tingkat pembacanya, sehingga peserta didik selaku pembaca belum paham dengan isi buku teks tersebut.

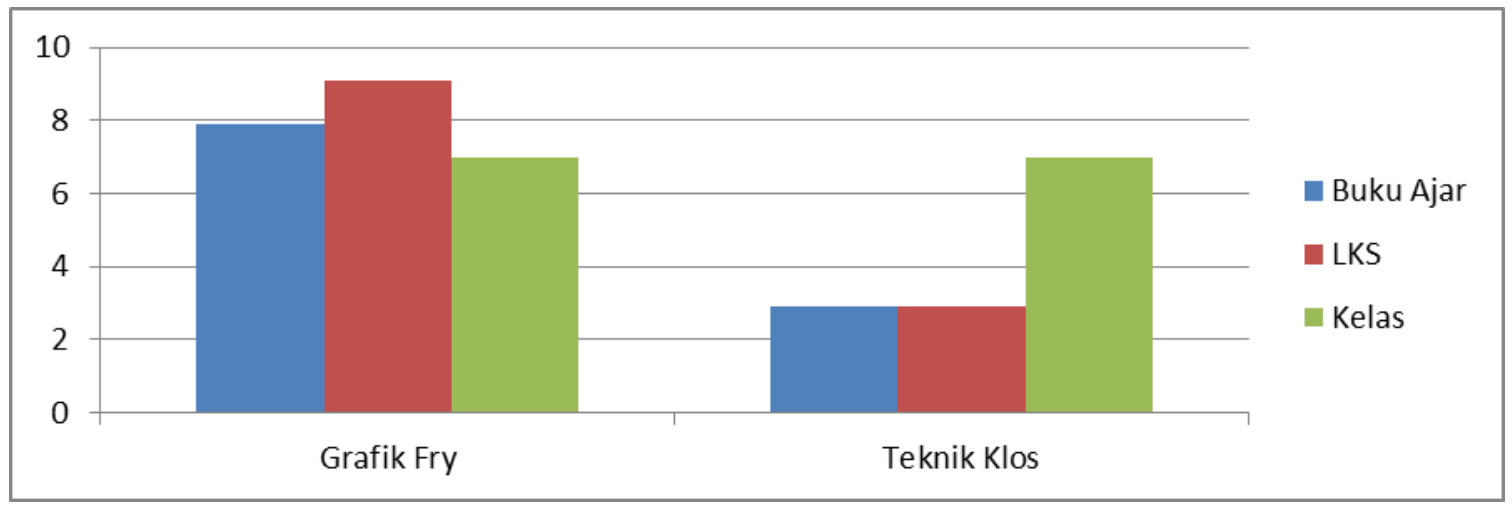


Berdasarkan diagram di atas, dapat disimpulkan bahwa buku ajar yang digunakan di Kota Madiun belum tepat sasaran, karena berdasarkan penghitungan buku ajar tersebut cocok untuk siswa kelas 6 (SD), 7 dan 8 (SMP).

Berdasarkan keenam wilayah tersebut dapat disimpulkan sebagai berikut.

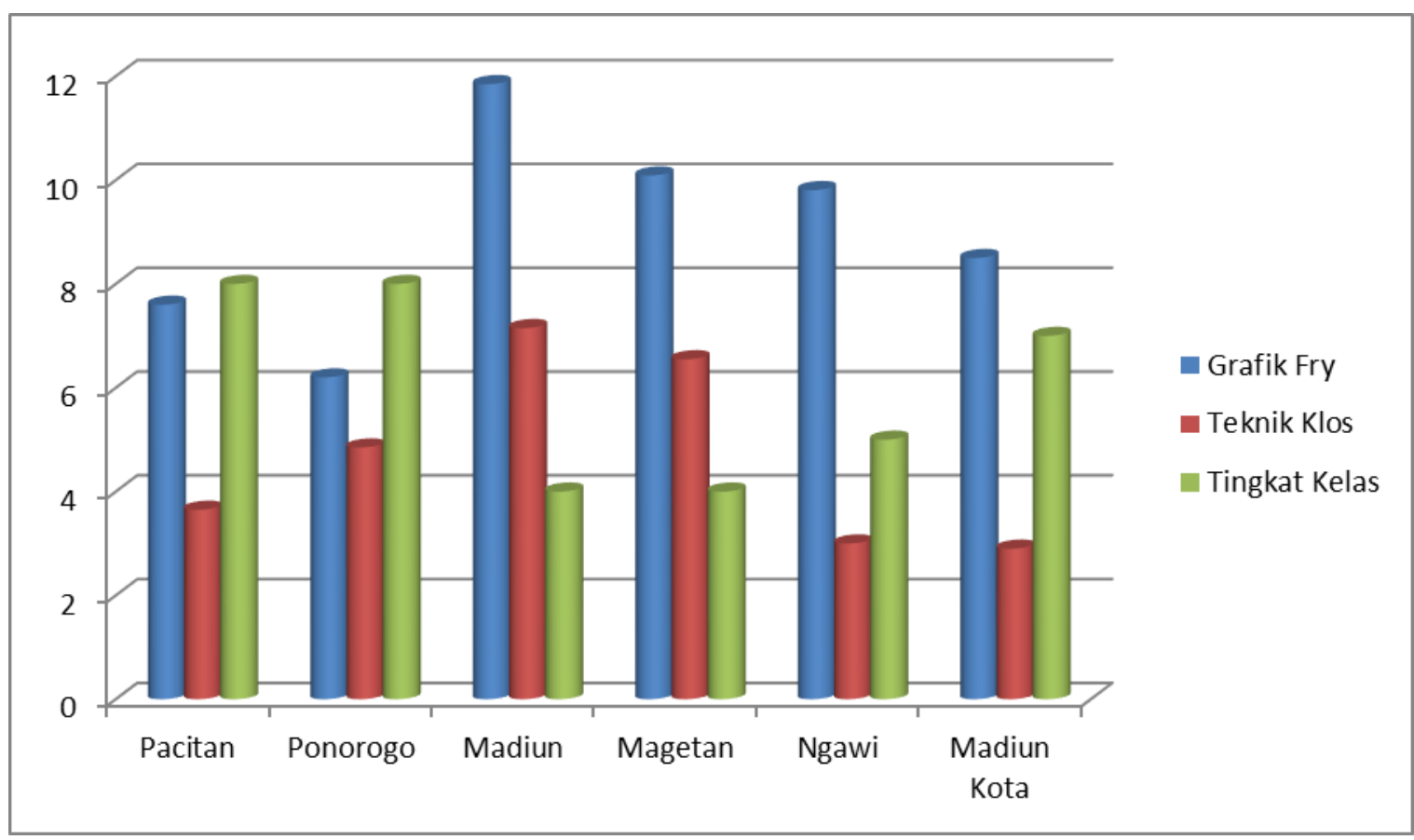

Berdasarkan diagram di atas, wilayah yang sudah menggunakan buku ajar yang sesuai dengan tingkat keterbacaannya adalah wilayah Kabupaten Madiun, Magetan, dan Ngawi, sedangkan ketiga wilayah yang lain yakni Kabupaten Pacitan, Ponorogo, dan Madiun Kota belum sesuai, karena terlalu tinggi, yakni untuk kelas 7 dan 8, hal itu berarti buku ajar itu sesuai untuk tingkat SMP.

\section{SIMPULAN}

Berdasarkan hasil analisis data dan pembahasan yang telah dipaparkan pada bab sebelumnya, maka dapat ditarik simpulan sebagai berikut.

\section{8 | http://journal.unesa.ac.id/index.php/paramasastra}


1. Buku teks yang dipakai di Kabupaten Pacitan belum sesuai sasaran karena berdasarkan kedua teknik, hasilnya menunjukkan bahwa buku teks yang dipakai saat ini sesuai untuk kelas SMP dan bukan SD.

2. Buku teks yang dipakai di Kabupaten Ponorogo belum sesuai sasaran karena berdasarkan kedua teknik, hasilnya menunjukkan bahwa buku teks yang dipakai saat ini sesuai untuk kelas SMP dan bukan SD.

3. Buku teks yang dipakai di Kabupaten Madiun sudah sesuai sasaran karena berdasarkan kedua teknik, hasilnya menunjukkan bahwa buku teks yang dipakai saat ini sudah sesuai untuk kelas IV SD.

4. Buku teks yang dipakai di Kabupaten Magetan sudah sesuai sasaran karena berdasarkan kedua teknik, hasilnya menunjukkan bahwa buku teks yang dipakai saat ini sudah sesuai untuk kelas IV SD.

5. Buku teks yang dipakai di Kabupaten Ngawi sudah sesuai sasaran karena berdasarkan kedua teknik, hasilnya menunjukkan bahwa buku teks yang dipakai saat ini sudah sesuai untuk kelas IV SD.

6. Buku teks yang dipakai di Kota Madiun belum sesuai sasaran karena berdasarkan kedua teknik, hasilnya menunjukkan bahwa buku teks yang dipakai saat ini sesuai untuk kelas SMP dan bukan SD.

Berdasarkan hal di atas, wilayah yang sudah menggunakan buku ajar yang sesuai dengan tingkat keterbacaannya adalah wilayah Kabupaten Madiun, Magetan, dan Ngawi, sedangkan ketiga wilayah yang lain yakni Kabupaten Pacitan, Ponorogo, dan Madiun Kota belum sesuai, karena terlalu tinggi, yakni untuk kelas 7 dan 8 , hal itu berarti buku ajar itu sesuai untuk tingkat SMP.

\section{DAFTAR PUSTAKA}

http://journal.unesa.ac.id/index.php/paramasastra | 39 
Arikunto, Suharsimi. 2012. Prosedur Penelitian Suatu pendekatan Praktek.

Jakarta: Rineka Cipta

Chaniago, Sam Mukhtar et al. 1996. Aspek Keterpaduan dan Keterbacaan Wacana Buku Ajar Bahasa Indonesia untuk Kelas I SMU. Jakarta: IKIP Jakarta.

Depdiknas. 2000. Keterbacaan Kalimat Bahasa Indonesia dalam Buku Pelajaran SLTP. Jakarta: Pusat Bahasa Departemen Pendidikan Nasional.

Harjasujana, A.S. dan Mulyati Y. 1996. "Bahan Ajar Membaca dan Keterbacaan” dalam Membaca 2. Jakarta:Ditjen Dikdasmen.

Laksono, Kisyani, dkk. 2007. Membaca 2. Jakarta: Universitas Terbuka

Pranowo, Dwiyanto Joko. 2007. "Alat Ukur Keterbacaan Teks Berbahasa Indonesia" dalam http://staff.uny.ac.id/sites/default/files/131764502/ Artikel\%20TESIS\%20S2\%20JOKO.pdf .Diunduh tgl 20 Januari 2016

Sulastri, I. 2008. "Teknik Isi Rumpang: Pemanfaatannya untuk Mengestimasi Keterbacaan Wacana" dalam Tridharma, Majalah Kopertis Wilayah IV Nomor 12 Tahun XX Juli 2008. Bandung: Kopertis IV. 